\section{Forklarer uforklart matoverfølsomhet?}

\author{
Personer med uforklart, selvrapportert matoverfølsomhet kan ha \\ en forstyrrelse i tarmfloraen som kan forklare plagene deres.
}

Personer som lider av matoverfølsomhet, men der undersøkelser ikke gir noen tegn på dette, får ofte diagnosen uforklart, selvrapportert matoverfølsomhet eller irritabel tarm-syndrom. Plagene de har er oppblåsthet, ubehag i magen og avføringsforstyrrelser. Jørgen Valeur har undersøkt mulige biologiske mekanismer for disse mageplagene, med vekt på tykktarmens funksjon.

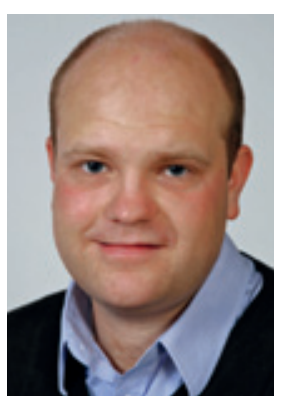
Jørgen Valeur. Foto Anne Sidsel Herdlevær, Universitetet i Bergen
- Vi undersøkte om vi kunne gjenskape symptomene til disse pasientene ved å gi dem tungt fordøyelige karbohydrater: fruktose, sorbitol og laktulose. Det kunne vi faktisk gjøre. Pasientene med irritabel tarm fikk mer

tarmgass var overraskende nok like stor i begge grupper, sier Valeur.

Pasientene med irritabel tarm hadde en annen fordeling av kortkjedede fettsyrer i avføringen enn de friske kontrollpersonene, noe som kan tyde på at tarmfloraen deres ikke fungerer normalt.

- Mange med uforklart, selvrapportert matoverfølsomhet føler at de ikke blir tatt på alvor. Denne kunnskapen kan gi dem en forklaring og vi kan berolige dem med at det ikke er noe farlig. De kan også få konkrete råd, f.eks. om å være tilbakeholdne med fiber. Frukt, grønt og grovt brød er ikke nødvendigvis bra for alle, og pasienter med irritabel tarm bør ikke spise som en hest, sier Valeur.

Han disputerte ved Universitetet i Bergen 8.10. 2010 for ph.d.-graden med avhandlingen Unexplained, self-reported food hypersensitivity. Explorative studies on mechanisms of abdominal symptom generation.

\section{Eline Feiring}

eline.feiring@legeforeningen.no trollgruppen. Men produksjonen av
Doktoravhandlinger

Se oversikt på side 2322

Tips oss om spennende

doktoravhandlinger

wWw.tidsskriftet.no/doktoravhandlinger

\section{Ordforklaringer}

Tykktarmens funksjon: Tykktarmen og dens bakterieflora spiller en avgjørende rolle i nedbrytningen av tungt fordøyelige næringsstoffer, spesielt karbohydrater. Ved mikrobiell fermentering (gjæring) av karbohydrater i tykktarmen dannes både gasser og kortkjedede fettsyrer. Tykktarmen har altså flere funksjoner enn å redusere vanninnholdet i avføringen (1).

Litteratur

1. Valeur J, Berstad A. Hvorfor har vi tykktarm? Tidsskr Nor Legeforen 2008; 128: 1299-300.

\title{
Kreftstamceller var ikke svaret?
}

\author{
Glioblastomer inneholder ulike typer kreftceller som kan gi \\ svulstdanning. Derfor er behandling rettet mot kreftstamcellene \\ ikke nok til å hindre kreftutvikling.
}

Glioblastoma multiforme (GBM) er svært aggressive hjernesvulster med høy dødelighet. Intensiv behandling med kirurgi, stråle- og kjemoterapi kan ikke kurere sykdommen. Påvisning av kreftstamceller i glioblastoma multiforme har gitt håp om behandling som kan hindre videre vekst av svulsten. Lars Prestegardens avhandling Intratumoral heterogeneity and tumor initiating cells in glioblastoma multiforme reiser tvil om betydningen av kreftstamceller i glioblastoma multiforme.

- Vi etablerte aggressive, svært infiltrerende glioblastoma multiforme med stamcelleliknende egenskaper i en rottemodell. Svulstene viste først ingen tegn til egen kardanning. Etter en lang serie implanteringer av kreftceller i nye rotter utviklet svulstene seg gradvis fra å være karuavhengige svulster med høyt uttrykk av gener som fremmer infiltrasjon, til å bli karavhengige svulster med lav grad av infiltrasjon, sier Prestegarden.

Han har studert de ulike kreftcellenes egenskaper og evne til å danne nye glioblastoma multiforme-svulster i rottemodellen. Han viser at ulike glioblastoma multiforme-kreftceller har ulike egenskaper, men cellene kan likevel danne nye svulster med omtrent samme effektivitet som de antatte kreftstamcellene.

- Resultatene våre får betydning for terapi. Nye behandlinger må rettes mot de fleste cellene i glioblastoma multiforme, ikke bare kreftstamcellene, og må hemme både kardanning og evnen til infiltrasjon, sier han.

Prestegarden disputerte for ph.d.-graden ved Universitetet i Bergen 10.9. 2010.

\section{Anne Forus \\ anneforu@online.no \\ Tidsskriftet}

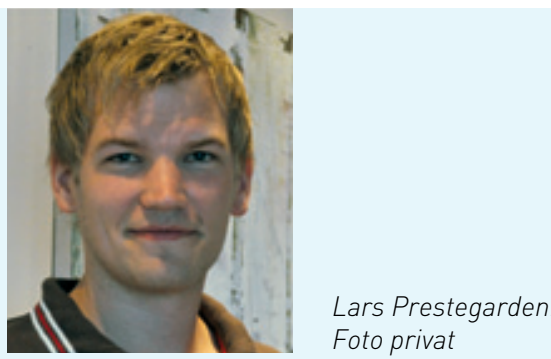

\section{Ordforklaringer}

Kreftstamceller: De kreftcellene i svulsten som antas å være ansvarlig for vekst, utvikling og tilbakefall av kreftsvulsten. Kreftstamceller utgjør en liten del av en svulst og har egenskaper som kan likne på det aktuelle vevets naturlige stamceller. 